\title{
How do motivational factors influence entrepreneurs' perception of business opportunities in different stages of entrepreneurship?
}

\begin{abstract}
The purpose of this paper is twofold: first, it analyses the relationship between optimism about the emergence of future entrepreneurial opportunities and the length of the entrepreneurial experience; second, it aims to identify the external factors that can moderate this relationship. Our empirical analysis is conducted on a cross-national sample of 450,000 individuals drawn from the Adult Population Survey (APS), which is collected by the Global Entrepreneurship Monitor (GEM) consortium and covers the period from 2009 to 2011. Our results find an inverted U-shaped relationship between the length of the entrepreneurial experience and our indicator of optimism. Additionally, the relationship between optimism and length of entrepreneurial experience is conditioned by a set of external-factor moderators, such as social capital and the individuals' perception of how valued entrepreneurship is as a career choice in their country.
\end{abstract}

Keywords: Optimism; Experience; Opportunism; Societal acceptance; Social capital.

\section{Introduction}

Over the last decade or so, entrepreneurship research has started to focus on the 'mental maps' individuals use to process external information in an attempt to reconstruct how entrepreneurs develop the unique knowledge structures (either scripted or heuristic) they use to assess potential entrepreneurial opportunities (Cooper and Saral, 2013; Grégoire et al., 2011; Baron, 1998; Mitchell et al., 2007; Mitchell et al., 2004; Chell, 2000; Lazear, 2004; Busenitz and Barney, 1997; Busenitz and Law, 1996). A key insight from this literature is that entrepreneurs tend to be subject to various biases (including over-optimism and over-confidence) when assessing potential opportunities (Baron, 2000; Gaglio, 2004; Groves et al., 2011; Haynie et al., 2010; Markman et al., 2002; Mitchell et al., 2002; Storey, 2014; Shook et al., 2003; Pillai, 2010). Moreover, many papers have found that entrepreneurs tend to be more optimistic about the future prospects of existing opportunities than non-entrepreneurs (e.g., Wright et al., 1997; Cooper et al., 1988; Keh et al., 2002).

Within this broad literature, some studies have started to focus on the role that previous entrepreneurial experience has in shaping optimism about the perceived attractiveness of existing opportunities among entrepreneurs. Jovanovic (1982) and Ucbasaran et al. (2009) point 
out that entrepreneurs learn about their abilities by running a business and changing their behaviour in response to their experience. However, the results from this literature have not offered a clear picture of the direction of the relationship between optimism and previous entrepreneurial experience. Some researchers have argued that learning and reflecting upon past entrepreneurial experience may make entrepreneurs more optimistic than their less experienced counterparts (Ucbasaran et al., 2010). By contrast, other authors have pointed out that the two types of entrepreneurs are not directly comparable as experienced entrepreneurs develop unique knowledge structures that allow them to assess the perceived attractiveness of an opportunity differently than novice entrepreneurs (Mitchell et al., 2000; Smith et al., 2009; Ucbasaran et al., 2010). Indeed, researchers have observed that experienced entrepreneurs may assess their own capabilities in managing the nascent venture and overcoming future difficulties differently from those of early-stage entrepreneurs (Levinthal and March, 1993; McMullen and Shepherd, 2006; Landier and Thesmar, 2009). Alternatively, DeTienne et al. (2008) and Dawson and Henley (2013) have pointed out that this is not always the case: some entrepreneurs realise that they have not assessed correctly the attractiveness of a business opportunity, adjust their thinking, and consequently adopt a different perspective on whether it is worth pursuing. In this context, Ucbsaran et al. (2010) have tried to reconcile these two positions, pointing out that the type of experience an entrepreneur has (e.g. whether it is successful or unsuccessful) conditions their level of optimism. Dawson and Henley (2013), however, point out that such research is incomplete and more analysis is needed to clarify how past entrepreneurial experience is associated with optimism.

We suggest that past research in this field has overlooked two factors when analysing the relationship between optimism and entrepreneurial experience. First, it is not previous entrepreneurial experience that matters per se but rather the length of this experience. Indeed, learning to recognise the potential prospects of an entrepreneurial opportunity requires time (Dimov, 2007; McCann and Vroom, 2015), and this process may affect the expectations individuals have about a potentially profitable opportunity. Second, we suggest that the relationship between optimism and entrepreneurial experience may be conditioned by a set of additional moderators that may make individuals more inclined to be optimistic about the potential of existing entrepreneurial opportunities. To clarify this point, it is important to start from one of the main tenets of social cognitive theory (Bandura, 1986; Wood and Bandura, 1989), which suggests that the cognitive process behind the recognition of opportunities (and the related optimism about future opportunities) is influenced by certain moderators (Carsrud and Brännback, 2011). For instance, the desire to emulate existing entrepreneurs may cause 
individuals to overlook costs associated with an entrepreneurial opportunity, and this may generate a positive view of the emergence of future entrepreneurial opportunities. A few studies have shown how moderators may influence the process of opportunity recognition (Rabin, 1998; Baron, 1998 and Brailey et al., 2001), but not too much is known about the relative importance of external factors in influencing the optimism individuals have about possible future opportunities. In addition, we argue that a variety of moderators may influence the relationship between optimism and length of entrepreneurial experience. For example, the desire to emulate existing entrepreneurs may be important for non-entrepreneurs or for inexperienced entrepreneurs, but not so much for experienced entrepreneurs.

Against this background, the purpose of this paper is to contribute to the existing literature on optimism among entrepreneurs - which considers the length of entrepreneurial experience and moderators as key factors - by addressing the following research questions: (a) How does the length of the past entrepreneurial experience influence optimism among entrepreneurs? (b) How do external-factor moderators affect the relationship between the length of entrepreneurial experience and optimism about the emergence of future entrepreneurial opportunities? Importantly in our analysis, we focus on a specific type of optimism-namely, optimism about the emergence of future entrepreneurial opportunities, which is commonly analysed in this literature (Schmitt et al., 2013; Zacher and Frese, 2011).

Our empirical analysis is conducted on a cross-national sample of 450,000 individuals drawn from the Adult Population Survey (APS), which is collected by the Global Entrepreneurship Monitor (GEM) consortium and covers the period from 2009 to 2011. Additionally, the sample includes 35 countries. This large geographical coverage ensures that we can easily deal with cross-country (fixed) factors that can potentially influence our dependent variable. The use of this database, unlike other studies, allows us to have an integral vision of how optimism and length of experience relate to each other. The APS classifies individuals according to the length of their entrepreneurial experience by distinguishing potential entrepreneurs, novice entrepreneurs, and experienced entrepreneurs based on the length of their experience by using cut-off points that are commonly used by the entrepreneurship literature. To examine the relationship between optimism and length of entrepreneurial experience we use regression analysis, complemented by the relationship critical test by Liu et al. (2009) to further corroborate our findings.

The structure of the paper is as follows. In Section 2, we present the conceptual framework and Hypotheses. Section 3 describes the dataset and the variables. The results are presented in Section 4. Finally, some concluding remarks are offered in Section 5. 


\section{Theoretical Framework and Hypotheses}

\section{Cognitive perspectives and the entrepreneur}

Cognitive perspectives refer to the perceptions, analyses, and interpretations of the circumstances in which an action takes place (Baron, 1998; Busenitz and Barney, 1997; Grégoire et al., 2011; Mitchell et al., 2004; Mitchell et al., 2007). Scholars have recently turned to cognitive psychology to provide the psychological underpinnings of entrepreneurial behaviour (Ucbasaran et al., 2010). Entrepreneurship research that is based on the principles of cognitive psychology has become a significant sub-field (Baron, 2004; Mitchell et al., 2002; Ucbsaran et al., 2010). Mitchell et al. (2002, p. 97) defined entrepreneurial cognitions as 'the knowledge structures that people use to make assessments, judgments, or decisions involving opportunity evaluation, venture creation, and growth'. Further, Grégoire et al. (2011) pointed out that cognitive theory can be separated into two streams: one that focuses on cognition structures and one that focuses on cognition processes. The cognition-structures stream refers to gained knowledge while the cognition-processes stream deals with the processes of receiving and using knowledge. In our paper, we focus on cognitive processes, building on several studies that suggest there are aspects of cognition that may play a key role in certain stages of the entrepreneurial process and explain some differences between entrepreneurs and nonentrepreneurs (Baron, 1998; Douglas, 2009; Douglas and Shepherd, 2002).

Studies focusing on entrepreneurial cognition emphasise the use of heuristics by entrepreneurs (Baron, 2004). The result is that their decision-making and perceptions of the world around them are affected by several cognitive biases, such as over-optimism, overconfidence (i.e. belief in their ability to bring about a given result), and representativeness (i.e. willingness to generalize from a small number of observations) (e.g., Brännback and Carsrud, 2009; Krueger, 2007; Mitchell et al., 2002, Mitchell et al., 2004; Mitchell and Shepherd, 2010; Chaston and Sadler-Smith, 2012; Gorgievski and Stephan, 2016). Some studies have shown that entrepreneurs can be over-confident about their capabilities and over-optimistic about potential business opportunities (De Meza \& Southey, 1996; Helweg-Larsen and Shepperd, 2001; Koellinger et al., 2007; Storey, 2014; Ucbasaran et al., 2010). This means they underestimate risks, so they may have the tendency to perceive profitable business opportunities even though they may turn out not to be so. 
The role of subjective opinions in business decision-making is at the heart of a significant part of the literature on entrepreneurship (DeTienne et al., 2008; Ucbasaran et al., 2010; Dawson and Henley, 2013). Cognitive entrepreneurship literature suggests entrepreneurs may deduce too much from limited information and become over-confident in their judgments (Brailey et al., 2001; Dawson and Henley, 2013). This can be particularly relevant when trying to identify business opportunities. ${ }^{1}$ Recognising opportunities can be a long process which is articulated in two stages: first, individuals try to make sense of new information and eventually form beliefs on whether or not to enact a course of action; second, they follow the chosen course of action if they believe it could lead to a certain benefit. In both stages, personal expectations about the future influence individuals' assessment of the initial stream of information, as well as the future costs and benefits associated with the choice of a specific course of action.

Traditionally, the expectation that positive things will happen in the future is defined as optimism (Carver and Schider, 2003; Rego et al, 2012). In this paper, we will follow the conceptualization of optimism suggested by Zacher and Frese (2011), Ucbasaran et al (2010) and Wood et al. (2015). They focus on the perception and expectations of entrepreneurs with respect to the emergence of future business opportunities. Their view is that individuals focus on opportunities and optimism refers to their positive perceptions and expectations about the future benefits associated with these opportunities. First, this is a specific or situational perspective of optimism which assumes that optimism may vary over time, along with the several dimensions that make it up. Therefore, Tiger (1979, p.18) identifies optimism as an 'attitude associated with an expectation about the social or material future' (Tiger, 1979, p.18). Second, optimism is linked to specific circumstances and objectives and therefore it is a multidimensional concept. Indeed, the optimism of the entrepreneur draws from a variety of dimensions, like the outcome of the opportunities' search (Ucbasaran et al, 2010), the resources and skills that the entrepreneur assumes are needed for the development of a business project (Wood et al., 2015), as well as her personal attitude towards success (Storey, 2011, Westhead and Wright, 2011).

\section{Optimism and entrepreneurial experience}

The literature on cognitive entrepreneurship and opportunity recognition suggests that entrepreneurs identify opportunities by using cognitive frameworks that vary immensely,

\footnotetext{
${ }^{1}$ Please notice that in this paper, we do not distinguish between first-person opportunity and third-person opportunity since the focus is on generic business opportunities (McMullen and Shepherd, 2006).
} 
depending on the different experiences of individuals (Allison et al., 2000; Baron and Ensley, 2006; Huber et al., 2014). Cognitive research suggests that prior experience can interfere with, and cause biases in, thinking and learning (Bazerman, 1990; Fraser and Greene, 2006), implying that optimism could vary with the length of the experience. In this context, the literature provides contradictory arguments regarding the influence of experience on optimism in identifying opportunities.

Regarding the effects of entrepreneurial experience on the optimism, we anticipate that there is an inverse U-shaped relation between entrepreneurial experience and optimism. Firstly, less experienced entrepreneurs are more prone to over-optimism (Baron, 1998; Sanchez, 2012): indeed, Grégoire et al., (2010) and Mitchell et al. (2002a) have suggested that novice entrepreneurs might have an immature image of the obstacles and threats involved in the development of a new venture, and will be more likely to misjudge the future profitability of potential entrepreneurial opportunities than experienced entrepreneur (Baron, 1998; De Meza \& Southey, 1996; Helweg-Larsen and Shepperd, 2001; Ucbasaran et al., 2010). Second, some scholars have argued that optimism will increase with experience, as a consequence of learning while working for the business. Jovanovic (1982) argued that entrepreneurs gradually learn throughout their experience by engaging in the actual running of a business and changing their behaviour over time. Wright et al. (1998) and Ucbasaran et al. (2010) point out that the experience acquired through having started multiple new ventures offers benefits in terms of developing contacts (Danson, 1999), discovering the most appropriate sources of financing (Starr and Bygrave, 1991), learning managerial and technical skills (Wright et al., 1998), and identifying emerging market segments (Wright et al., 1997). Consequently, there is an increase in entrepreneurial self-efficacy (Zhao et al., 2005) and therefore, from this perspective, experience actually increases the optimism of the entrepreneur in their search for opportunities. However, Fraser and Greene (2006) and Ucbasaran et al. (2010) point out that this initial optimism about opportunities declines when the entrepreneur acquires more experience. Mitchell et al. (2000) found that the cognitive frameworks of experienced entrepreneurs become clearer and richer with experience compared to those used by novice entrepreneurs, and they tend to have more realistic perceptions of potentially profitable business opportunities. In addition, their heuristics change over time as they gain experience with the result that their expectations are better aligned to the actual future profitability of projects (Mitchell et al., 2007; Douglas, 2009). Evidence has shown that most of the start-ups do not last longer than 3.5 years (Amorós and Bosma, 2014; Shane, 2009), and in most cases those entrepreneurs should modify aggressively their initial thoughts or strategies to continue to be competitive (Douglas, 2009). 
Vice versa entrepreneurs, who have been working in the same industry for a considerable period of time, should have a realistic understanding of the benefits that opportunities can bring (Johnson, 2004; Shane, 2009). Thus, we hypothesize that the relationship between optimism and experience changes during the entrepreneurial process and most of the biases affecting novice entrepreneurs should be reduced to an equilibrium state where entrepreneurial optimism is aligned with realistic future scenarios. Combined together these arguments suggest that there is a turning point in the relationship between experience and optimism about entrepreneurial opportunities above which optimism declines with experience. Hence, we propose:

Hypothesis 1: Optimism is an inverse U-shaped function of entrepreneurial experience so that mature entrepreneurs will be less optimistic than potential entrepreneurs.

\section{Optimism and entrepreneurial experience: the moderating effect of external factors}

The literature on cognitive entrepreneurship suggests that individuals' attitudes towards entrepreneurship are shaped by internal and external motivators (Riketta and Nienaber, 2007; Carsrud and Brännback, 2011; Fehr and Falk, 2002; Oosterbeek, 2010). In our paper, we are going to concentrate on external motivators i.e. the external factors that reward behaviour. More specifically, we suggest that they moderate the relationship between optimism and length of entrepreneurial experience. External factors include financial reward and/or societal acceptance (Ryan and Deci, 2000; Walker and Brown, 2004; Ozgen and Baron, 2007). Individuals who live in countries or communities where entrepreneurship is considered an acceptable career option may tend to underestimate the costs associated with potential opportunities (Ryan and Deci, 2000). ${ }^{2}$ According to Carsrud et al. (2009) and Baron (2002), role models (i.e. existing successful entrepreneurs) may affect the perception individuals have about entrepreneurial opportunities (Ozgen \& Baron, 2007). Hence, we propose:

Hypothesis 2: External factors moderate the relationship between optimism about the emergence of opportunities and entrepreneurial experience.

Some empirical studies have suggested that the role of external factors in influencing entrepreneurs' behaviour and attitudes varies with their experience (Ryan and Deci, 2000;

\footnotetext{
${ }^{2}$ According to Davidsson (2015), opportunity confidence refers to the subjective evaluation of the attractivenessor lack thereof-of a stimulus as the basis for entrepreneurial activity (p.675).
} 
Walker and Brown, 2004). Novice entrepreneurs tend to be driven by external factors (e.g., financial rewards) in their activities, whereas internal factors may be more important for experienced entrepreneurs who may wish to pursue an opportunity to prove their capabilities (e.g., McMullen and Shepherd, 2006). Thus, being acquainted with other entrepreneurs or the existence of cultural support to entrepreneurship may affect the optimism that novice entrepreneurs have about future opportunities. Along this line, Tichy (2004) and Lee et al. (2008) point out that novelty can lead novice entrepreneur to diversify their goals, producing a substitution effect leading to over-optimism about other opportunities, and decreasing the level of optimism about current opportunities. Moreover, novice entrepreneurs tend to use less structured mental maps when assessing potential opportunities because of their lack of experience, producing external factors that affect their optimism with a greater variability (Allison et al., 2000; Baron and Ensley, 2006). Among experienced entrepreneurs external support is mostly used to confirm information and beliefs (Mitchell et al., 2007; Gibson and Sanbonmatsu, 2004; Mitchell et al., 2000). In other words experienced entrepreneurs will discard information that is not consistent with the existing beliefs. Hence, we propose:

Hypothesis 3: The moderating effect of external factors on the optimism about the emergence of opportunities varies with the entrepreneurial experience so that for the same level of external factors, mature entrepreneurs will be less optimistic than potential entrepreneurs.

\section{Methods}

For the empirical analysis, the main data source is the pooled APS, which covers 35 countries over the period 2009-2011. The final number of observations is 459,581.

The APS is assembled by the GEM research consortium and is designed to capture information about respondents' involvement in venture creation as well as their motives and aspirations toward entrepreneurship. In this respect, it is a quite unique data resource as it captures start-up efforts at a very early stage as well as information about established businesses (Reynolds et al., 2005). The APS is the main source of information about entrepreneurship at the cross-national level as it provides internationally comparable data on entrepreneurial activities across the world. Unsurprisingly, it has been widely used to identify the drivers of entrepreneurship in cross-national settings (Alvarez et al., 2014; Amorós and Bosma, 2014; Koellinger, 2008).

As a dependent variable, we will use optimism in the recognition of entrepreneurial opportunities. As we have pointed out above, we conceptualize optimism using linkages with 
specific circumstances and objectives, and we assume it is a multidimensional variable (Zacher and Frese, 2011, Ucbasaran et al, 2010, Wood et al., 2015). Therefore, to capture optimism, a cumulative index is needed as pointed out by Acs et al. (2014) and Driver and Guedes (2012). The APS-GEM questionnaire contains a set of questions on the entrepreneurial perception of opportunities, skills, and resources, as well as questions on attitude. More specifically, respondents are asked whether they agree with the following three statements: (i) In the next six months there will be good opportunities for starting a business in the area where you live; (ii) You perceive yourself to have the knowledge, skills, and experience required to start a new business; and (iii) Fear of failure would not prevent you from starting a business. The variables range originally between -2 to 2 (refused to answer, N/A, no, yes); however, we have dropped the observations corresponding to individuals who refused to answer the question or for whom the question was not applicable ${ }^{3}$. Following Acs et al. (2014), we then combine the replies to these three variables and create a cumulative index for optimism that varies from 0 to 3 ; individuals are considered optimistic if they agree with all of them.

Methodologically, a cumulative index requires: (a) that the components of the index be uncorrelated (Miller, 1996, 1986); (b) that the scales of the variables be harmonised; and (c) that the cumulative index reflects the behaviour of the population (Acs et al., 2014). Our index satisfies all the requirements. First, the three components of the index are not correlated as the Cronbach's Alpha is lower than 0.6. Second, the scale of the variables is consistent with each other. Finally, the index reflects the behaviour of the population as suggested by the results of the ANOVA analysis conducted on the full data-set.

As for the independent variables, we created a set of binary indicators to distinguish first between entrepreneurs and non-entrepreneurs and then between 1) potential entrepreneurs 2) nascent entrepreneurs (business duration from zero to three 3 months) and non-entrepreneurs, 3) baby entrepreneurs (business duration from three months to three-and-a-half years) and nonentrepreneurs, and 4) established entrepreneurs (business duration more than three-and-a-half years) and non-entrepreneurs. This classification of entrepreneurs as well as the employed cutoff points has been suggested by Reynolds et al. (2005, p. 209) and is commonly used by the literature on entrepreneurship. Two variables were included as moderators in the empirical analysis. The first variable proxies individual-level social capital; respondents were asked to respond to the following question: Do you know someone personally who started a business in the past 2 years? The variable ranges originally between -2 to 2 (refused to answer, N/A, no,

\footnotetext{
${ }^{3}$ The total number of deleted observations is 124,800 representing $27 \%$ of the original database.
} 
yes) and tries to capture the possibility that role models may influence optimism among respondents (Amorós et al., 2013; Arenius and Minniti, 2005; Scherer et al., 1989). In our analysis, by contrast, we discarded the individuals who refused to answer and for whom the question was not applicable, and created a dummy variable taking the value of 1 for individuals who responded 'yes' and 0 otherwise. The second moderator (i.e. societal acceptance of entrepreneurship as a career option) captures respondents' perceptions about the extent to which entrepreneurial activities are socially accepted. This individual-level variable was constructed by combining the answers to the following questions: (i) Do you agree that most people consider entrepreneurship a desirable career choice?; (ii) Do you agree that successful entrepreneurs have a high social status?; and (iii) Do you agree that cases of successful entrepreneurship have plenty [of] media attention? The index varies by individuals and has four values: 0 if the respondent replies 'no' to all three questions, 1 if he or she replies positively only to one question, 2 if the respondent replies 'yes' to two questions, and 3 if the respondent replies positively to all questions. In addition, in this empirical specification, we controlled for gender, (the log of) age, as well as the year the survey was administered. Gender was coded as a dummy variable taking the value of 0 for females and 1 for males. Finally, we included a set of country dummies to control for time-invariant factors that may be correlated to our dependent variable.

Table 1 presents the main descriptive statistics for our variables while the correlation matrix is presented in Table 2.

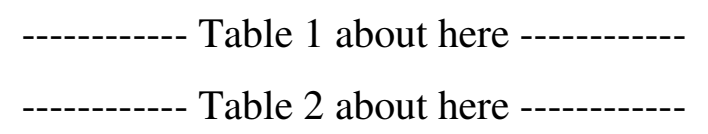

Before it tested the hypotheses, we calculate variance inflation factors (VIFs) for each predictor variable to check for multicollinearity. VIF values greater than 10 indicate reasons for concern due to collinearity among the variables, and tolerance values less than 0.1 indicate collinearity among variables. The VIFs values were below the value of two, indicating that multicollinearity was not an issue in our analysis. Therefore, our values do not suffer from collinearity.

\section{Results}

The results are presented in Table 3 and 4. Table 3 presents the results of seven models, estimated using OLS. Model 1 is the baseline model that captures the relationship between optimism and the entrepreneurial status of the individual, whereas Models 2-7 model the relationship between optimism and the length of entrepreneurial experience of each respondent. Table 4 shows the same models where moderators (i.e., social capital and societal acceptance 
of entrepreneurship) are included as additional variables. We estimated a set of models that include the interaction term between each proxy of the length of entrepreneurial experience and each moderator.

Estimates from all the models suggest that men tend to be more optimistic than women. In addition, the older an individual is the less optimistic about future entrepreneurial opportunities he or she becomes. These results are consistent with the entrepreneurship literature, which states that women tend to be more risk-averse than men (Gupta, 2009; Kwong et al., 2012) and that young individuals are more likely to start a new firm than older individuals (Lévesque and Minniti, 2006).

Table 3 about here

Figure 1 about here

Both Table 3 and Figure 1 suggest that entrepreneurs tend to be more optimistic than nonentrepreneurs. Indeed, the results of the regression model suggest a positive association between optimism and entrepreneurial experience (Models 3 to 6). These results are consistent with previous studies and with the general notion that entrepreneurs appear to structure the reality they live in differently than non-entrepreneurs (Brannback and Carsrud, 2009), either in terms of entrepreneurial opportunities, (Douglas, 2009, Grégoire et al., 2010; Groves et al., 2011; Haynie et al., 2012), or in terms of perceived costs and risks (Koellinger et al., 2007; Elfving et al., 2009. However, this is not the case among non-entrepreneurs. Figure 1 shows that the value of the optimism index is null among non-entrepreneurs: this may explain their lack of interest in possible entrepreneurial opportunities and their desire to look for, for example, other work alternatives (Arranz et al., 2018).

Regarding the effect the experience in the opportunism and experience, the results in Table 3 confirm Hypothesis 1. Models 3-7 suggest an initial increase of the optimism between potential and nascent entrepreneur, however as individuals become more experienced, they are less likely to score high on the index of optimism, confirming the inverse U-shaped relationship between optimism and experience. In addition, we use the test suggested by Liu et al. (2009) to identify which models perform better in explaining the variance of the dependent variable. More specifically, we compared the adjusted $\mathrm{R}^{2}$ of the different regression models. For example, if we compare the $\mathrm{R}^{2}$ of Model 7 vs the $\mathrm{R}^{2}$ of model 5 and Model 4 respectively, we find that $\mathrm{R}^{2}$ Model7- $\mathrm{R}^{2}$ Model5 $=0.220-0.155=0.065$, while the equivalent figure when comparing Model 7 against Model 4 is $(0.220-0.161)=0.059$. Since $\Delta R^{2}$ Model7-Model5 $>\Delta R^{2}$ Mode7-Model4, we can conclude that the contribution of the variable 'nascent entrepreneurs' to explaining the variance of the dependent variable is larger than the contribution of the variable 'baby business'. We 
have done the same for all the other variables of interest (potential, nascent, baby and established) in Table 3. These results confirm Hypothesis 1, taking into account the coefficients of the regression model and the contribution of the variance explained. This is a clear contribution of the paper to the literature. Indeed, while there are studies arguing that entrepreneurs' subjective knowledge and intuition are shaped by experience (e.g., Kor et al., 2007), and that individuals with no prior business-ownership experience detect fewer entrepreneurial opportunities (e.g., Baron, 2006), our results suggest that optimism about the emergence of generic business opportunities is not enhanced by experience. Figure 1 shows that the value of the optimism index decreases as entrepreneurs become more experienced.

Table 4 re-examines the relationship between experience and optimism, but this time we include external moderators among the regressors. The results are similar to those reported in Table 3 and, indeed, the shape of the relationship between the optimism index and the length of entrepreneurial experience (Figure 2) is remarkably similar to what we observe in Figure 1. In addition, each proxy for social capital and social acceptance of entrepreneurship is significant and positive. As mentioned above, we have interacted the moderators with each indicator of the type of entrepreneur, testing the effect of the length of the entrepreneurial experience and the interactions with the moderators (Table 5). The results show that these variables are significant and confirm that external moderators condition the relationship between the optimism index and length of entrepreneurial experience-thus supporting Hypotheses 2.

Tables 4 and 5 about here

Figure 2 about here

Table 5 shows how each moderating variable affects the relationship between entrepreneurial experience and optimism (Hypothesis 3). In line with what we expect from Hypothesis 3, the results show that the impact of each moderating variable varies the length of the entrepreneurial experience. For example, model 7 in table 5 suggests that societal acceptance moderates the relationship between optimism and potential entrepreneurship and nascent entrepreneurship. Thus, societal acceptance has a positive impact on optimism among potential entrepreneurs and a negative impact among nascent entrepreneurs ${ }^{4}$. In addition, among experienced entrepreneurs, the interaction term is not significant. Furthermore, Model 7 in Table 5 also suggests that the joint effect of social capital and length experience moderates the optimism, but we observe a variability in the coefficients of the regression model. This suggests

\footnotetext{
${ }^{4}$ The optimism values are 0.060 for potential entrepreneurs in Model $7(0.047+0.013)$; and 0.023 for nascent entrepreneurs (0.047-0.024).
} 
that the overall impact of social capital reduces the optimism, but the more experienced the entrepreneur is, the less important social capital is as a moderating effect ${ }^{5}$. Figures 3 and 4 summarize these findings graphically. Figure 3 shows how the relationship between optimism and entrepreneurial experience varies among individuals that belong to communities where entrepreneurship is accepted as a career option. Figure 4 shows that the relationship between optimism and entrepreneurial experience when the moderating effect of social capital is taken into account. Both sets of results suggest that external moderators have a larger impact on optimism among less experienced entrepreneurs than among the more experienced ones. The results are in line with the works Allison et al. (2000) and Baron and Ensley (2006), who show that novice entrepreneurs have greater variability in the optimism than experienced entrepreneur, as consequence, novice entrepreneurs tend to use less structured mental maps when assessing potential opportunities because of their lack of experience.

-- Figure 3 about here

Figure 4 about here

\section{Discussion and Conclusions}

The present study expands the research on entrepreneurship in a number of ways. Firstly, it provides evidence that supports claims in the literature about the nature of entrepreneurial opportunities. Entrepreneurs' actions are driven primarily by their perceptions (Arenius and Minitti, 2005). Moreover, even when these perceptions are influenced by external factors, the definition of a good opportunity is personal and it is only nurtured by external factors that shape these interpretations. This is likely to be especially true for potential and nascent entrepreneurs who are looking to start businesses under the biases of entrepreneurial lenses (Douglas, 2009) and entrepreneurial euphoria (Cooper et al., 1988). Entrepreneurs tend to be significantly more optimistic than non-entrepreneurs, so it seems they use their subjective interpretations to give meaning to objects and situations, as well as using concepts to connect the dots (Baron, 2006). For example, desiring to set up a business may increase entrepreneurs' likelihood of discovering business opportunities since they are in an active state of entrepreneurial alertness.

Secondly, the paper helps to clarify the relationship between optimism and experience. Much of the venture-creation process involves seeking and processing information, which makes this activity critical in entrepreneurship (Kirzner, 1979). Some studies have argued that experienced

\footnotetext{
${ }^{5}$ Also, the optimism values are 0.19 for potential entrepreneurs (0.328-0.138); 0.226 for nascent entrepreneurs (0.328-0.102); 0.27 for baby business (0.328-0.057); and 0.278 for established business $(0.328-0.050)$.
} 
entrepreneurs - given their exposure to customers, competitors, and suppliers, among otherstend to have a more external orientation as they are more aware of external pressures and challenges (e.g., Cooper et al., 1995). Other studies, however, have suggested that entrepreneurs fail to incorporate external information into their decision-making process since they believe they can successfully pursue an opportunity independently of the environment (e.g., Mitchell and Shepherd, 2010). This phenomenon is intensified for entrepreneurs with successful prior ventures, such as serial entrepreneurs. Consequently, the balance between personal attitude and external environment as the drivers of entrepreneurs' behaviours seems to be incomplete, at least in regard to the role experience plays in influencing each one. Further, Grégoire et al. (2011) observed that it is not totally clear whether entrepreneurs' cognitive differences originate from idiosyncratic factors and events that precede their efforts and actions or from the very experience of undertaking entrepreneurship (Foo et al., 2009). In this regard, our results have shown that experienced entrepreneurs are less optimistic than novice entrepreneurs, and we find an inverted U-shaped relationship between entrepreneurial experience and optimism (Hypothesis 1). Individuals with entrepreneurial intentions and early-stage entrepreneurs (i.e., entrepreneurs in the subsequent stages of the entrepreneurial process) can be optimistic in comparative terms about business opportunities, skills, and capabilities. While this study has not focused on why some individuals choose to become entrepreneurs (Baron, 2004; Mitchell et al., 2007; Simon et al., 2000), the fact that mature entrepreneurs are less likely to be optimistic than novice entrepreneurs suggests that entrepreneurial experience can make a difference in the way individuals perceive business opportunities and their capabilities.

Lastly, we find that the relationship between optimism and length of entrepreneurial experience is conditioned by external moderators (Hypotheses 2 and 3). Our findings suggest that entrepreneurs who live in communities where entrepreneurship is perceived as a respectable career option (i.e. entrepreneurship is culturally supported) are not more optimistic than those who live in areas where there is no cultural support for entrepreneurship. The findings on the importance of social capital are quite interesting: potential and novice entrepreneurs who work in communities where there is an informal support network for entrepreneurs tend to be less optimistic about future entrepreneurial opportunities than those who do have access to these informal networks. Knowing other entrepreneurs personally reduces the likelihood of having optimism. Moreover, the effect of these external factors vary in relation to entrepreneurial experience. This effect decreases in the case of experienced entrepreneurs, where the reduction of optimism is lower than in the case of novice entrepreneurs, showing the low permeability of the experienced entrepreneur before external factors. 
As with every study, there are some limitations to be considered, such as the variables used to capture each concept, such as optimism or social capital, among others. Despite this issue, every variable included in this study has been used in previous research (e.g. Koellinger et al., 2007; Arenius and Minitti, 2005). In this sense, they have academic support and reliability (Alvarez et al., 2014; Amorós et al., 2013)—even if it may be more fruitful to capture more aspects involved in each construct. This study provides a better understanding of the likelihood of over-optimism about perceptions of future business opportunities during several entrepreneurial phases. However, it is not possible to speculate about any change (i.e., increase or decrease) in the degree of optimism in different entrepreneurial stages or about how entrepreneurs increase or decrease their over-optimism as they go through different entrepreneurial phases. It is important to consider that optimism was evaluated using a set of variables, none of which suggest that we are measuring a threshold about the positive or negative influence on opportunity recognition. As a result, there is no information about the degree of the measured construct. Further, since this study does not use panel data, it is not possible to infer information about individuals' progress through the entrepreneurial process.

It may be interesting for future studies to compare unrealistic optimism among entrepreneurs with peers in others stages of the entrepreneurial process; for instance, by testing whether entrepreneurs' expectations of growth are possible to obtain. Additionally, considering that several of the measures employed in the second study were self-reported and evaluated with single-item factors, replication studies with additional measures for these variables are necessary before the present results can be accepted with confidence (even though these measures were based on measures used in previous research and have been shown to possess acceptable reliability and validity). 


\section{References}

Acs, Z. J., Autio, E., \& Szerb, L. (2014). National systems of entrepreneurship: Measurement issues and policy implications. Research Policy, 43(3), 476-494.

Allinson, C. W., Chell, E., \& Hayes, J. (2000). Intuition and entrepreneurial behaviour. European Journal of Work and Organizational Psychology, 9(1), 31-43.

Álvarez, C., Urbano, D., \& Amorós, J. E. (2014). GEM research: achievements and challenges. Small Business Economics, 42(3), 445-465.

Amorós, J. E., \& Bosma, N. (2014). Global Entrepreneurship Monitor, 2013 Global Report. Babson Park, MA, U.S.: Babson College; Santiago, Chile: Universidad del Desarrollo; Kuala Lumpur, Universiti Tun Abdul Razak and London, U.K.: Global Entrepreneurship Research Association

Amorós, J. E., Bosma, N., \& Levie, J. (2013). Ten years of Global Entrepreneurship Monitor: accomplishments and prospects. International Journal of Entrepreneurial Venturing, 5(2), 120-152.

Ardichvili, A, Cardozob, R., \& Rayc, S. (2003). A theory of entrepreneurial opportunity identification and development. Journal of Business Venturing, 18(1), 105-123.

Arenius, P., \& Minniti, M. (2005). Perceptual variables and nascent entrepreneurship. Small Business Economics, 24(3), 233-247.

Arranz, N., Arroyabe, M. F., \& Fdez. de Arroyabe, J. C. (2018). Entrepreneurial intention and obstacles of undergraduate students: the case of the universities of Andalusia. Studies in Higher Education, 1-14.

Bandura, A. (1977). Self-efficacy: Toward a unifying theory of behavioural change. Psychological Review, 84(2), 191-215.

Bandura, A. (1986). Social foundations of thought and action: A social cognitive theory. Englewood Cliffs, NJ: Prentice-Hall.

Baron, R. A. (1998). Cognitive mechanisms in entrepreneurship: Why and when entrepreneurs think differently than other people. Journal of Business Venturing, 13(4), 275-294.

Baron, R. A. (2000). Psychological perspectives on entrepreneurship: cognitive and social factors in entrepreneurs' success. Current Directions in Psychological Science, 9, 15-18.

Baron, R. A. (2002). OB and entrepreneurship: the reciprocal benefits of closer conceptual links. Research in Organizational Behavior, 24, 225-269.

Baron, R. A. (2004). The cognitive perspective: a valuable tool for answering entrepreneurship's basic "why” questions. Journal of Business Venturing, 19(2), 221-239. 
Baron, R. A. (2006). Opportunity recognition as pattern recognition: How entrepreneurs "connect the dots" to identify new business opportunities. The Academy of Management Perspectives, 20(1), 104-119.

Baron, R. A., \& Ensley, M. D. (2006). Opportunity recognition as the detection of meaningful patterns: Evidence from comparisons of novice and experienced entrepreneurs. Management Science, 52(9), 1331-1344.

Bird, B. (1988). Implementing entrepreneurial ideas: The case for intention. Academy of Management Review, 13(3), 442-453.

Brailey, K., Vasterling, J. J., \& Franks, J. J. (2001). Memory of psychodiagnostic information: Biases and effects of expertise. The American Journal of Psychology, 114(1), 55.

Brännback, M., \& Carsrud, A. (2009). Cognitive maps in entrepreneurship: researching sense making and action, in Understanding the Entrepreneurial Mind: Opening the Black Box. Eds. A. Carsrud and M. Brännback, pp. 75-96.

Brazerman, M. H. \& Moore, D. A. (2009). Judgement in Managerial Decision Making. John Wiley \& Sons, Inc., Hoboken, N.

Busenitz, L. W., \& Barney, J. B. (1997). Differences between entrepreneurs and managers in large organizations: Biases and heuristics in strategic decision-making. Journal of Business Venturing, 12(1), 9-30.

Busenitz, L., \& Lau, C. (1996). A cross-cultural cognitive model of new venture creation. Entrepreneurship Theory and Practice, 20, 4, 25-39.

Carsrud, A., \& Brännback, M. (2011). Entrepreneurial motivations: what do we still need to know? Journal of Small Business Management, 49, 9-26.

Carsrud, A., Brännback, M. Elfving, J., \& Brandt, K. (2009). Motivations: The Entrepreneurial Mind and Behavior. In Understanding the Entrepreneurial Mind: Opening the Black Box. Eds. A. Carsrud and M. Brännback, pp. 141-166.

Carver, C. S., Scheier, M. F., \& Segerstrom, S. C. (2010). Optimism. Clinical Psychology Review, 30, 879-889.

Chaston, I. and Sadler-Smith, E. (2012). Entrepreneurial Cognition, Entrepreneurial Orientation and Firm Capability in the Creative Industries. British Journal of Management, 23, 415432.

Chell, E. (2000). Towards researching the"opportunistic entrepreneur": A social constructionist approach and research agenda. European Journal of Work and Organizational Psychology, 9(1), 63-80. 
Cooper, A. C., Folta, T. B., \& Woo, C. (1995). Entrepreneurial information search. Journal of Business Venturing, 10(2), 107-120.

Cooper, A. C., Woo, C. Y., \& Dunkelberg, W. C. (1988). Entrepreneurs' perceived chances for success. Journal of Business Venturing, 3(2), 97-108.

Cooper, D. \& Saral, K. (2013). Entrepreneurship and team participation: An experimental study. European Economic Review, 59, 126-140.

Dawson, C., \& Henley, A. (2013). Over-optimism and entry and exit from self-employment. International Small Business Journal, 31(8), 938-954.

De Meza, D., \& Southey, C. (1996). The borrower's curse: optimism, finance and entrepreneurship. Economic Journal, 106, 375-386.

Deci, E., \& Ryan, R. (2008). Self-determination theory: A macro theory of human motivation, development, and health. Canadian Psychology/Psychologie canadienne, 49, 182-185.

DeTienne, D. R., Shepherd, D. A., \& De Castro, J. O. (2008). The fallacy of "only the strong survive": The effects of extrinsic motivation on the persistence decisions for underperforming firms. Journal of Business Venturing, 23(5), 528-546.

Dimov, D. (2007). Beyond the single-person, single-insight attribution in understanding entrepreneurial opportunities. Entrepreneurship Theory and Practice, 31(5), 713-731.

Dimov, D. (2010). Nascent entrepreneurs and venture emergence: Opportunity confidence, human capital, and early planning. Journal of Management Studies, 47(6), 1123-1153.

Douglas, E. (2009). Perceptions - Looking at the world through entrepreneurial lenses. In, A. Carsrud \& M. Brännback (Eds.), Understanding the entrepreneurial mind. New York, NY: Springer. pp. 3-22.

Driver, C., \& Guedes, M. J. C. (2012). Research and development, cash flow, agency and governance: UK large companies. Research Policy, 41(9), 1565-1577.

Edelman, L., \& Yli-Renko, H. (2010). The impact of environment and entrepreneurial perceptions on venture-creation efforts: bridging the discovery and creation views of entrepreneurship. Entrepreneurship Theory and Practice, 34(5), 833-856.

Elfving, E., Brännback, M., \& Carsrud, A. (2009). Toward A Contextual Model of Entrepreneurial Intentions. In, A. Carsrud \& M. Brännback (Eds.), Understanding the entrepreneurial mind. New York, NY: Springer, pp. 23-34.

Farmer, S., Yao, X., \& Kung-Mcintyre, K. (2011). The behavioral impact of entrepreneur identity aspiration and prior entrepreneurial experience. Entrepreneurship Theory and practice, 35(2), 245-273. 
Fehr, E. \& Falk, A. (2002). Psychological foundations of incentives. European Economic Review, 46, 687-724.

Fonseca, R., Lopez-Garcia., P., \& Pissarides, C. (2001). Entrepreneurship, start-up costs and employment. European Economic Review, 45, 692-705.

Foo, M. D., Uy, M. A., \& Baron, R. A. (2009). How do feelings influence effort? An empirical study of entrepreneurs' affect and venture effort. Journal of Applied Psychology, 94(4), 1086.

Fraser, S., Greene, F., 2006. The effects of experience of entrepreneurial optimism and uncertainty. Economica 73, 169-192.

Gibson, B., \& Sanbonmatsu, D. M. (2004). Optimism, pessimism, and gambling: The downside of optimism. Personality and Social Psychology Bulletin, 30(2), 149-160.

Gorgievski, M.J. \& Stephan, U. (2016). Advancing the Psychology of Entrepreneurship: A Review of the Psychological Literature and an Introduction. Applied Psychology, 65 (3), 437-468.

Gaglio, C. M. (2004). The role of mental simulations and counterfactual thinking in the opportunity identification process. Entrepreneurship Theory and Practice, 28(6), 533-552.

Grégoire, D., Corbett, A., \& McMullen, J. (2011). The cognitive perspective in entrepreneurship: an agenda for future research. Journal of Management Studies, 48(6), 1443-1477.

Grégoire, D., Shepherd, D., \& Lambert, L. (2010). Measuring Opportunity-Recognition Beliefs: Illustrating and Validating an Experimental Approach. Organizational Research Methods, 13(1), 114-145.

Groves, K., Vance, C., \& Choi, D. (2011). Examining entrepreneurial cognition: an occupational analysis of balanced linear and nonlinear thinking and entrepreneurship success. Journal of Small Business Management, 49(3), 438-466.

Gupta, V. K., Turban, D. B., Wasti, S. A., \& Sikdar, A. (2009). The role of gender stereotypes in perceptions of entrepreneurs and intentions to become an entrepreneur. Entrepreneurship Theory and Practice, 33(2), 397-417.

Haynie, J. M., Shepherd, D. A., \& Patzelt, H. (2012). Cognitive adaptability and an entrepreneurial task: The role of metacognitive ability and feedback. Entrepreneurship Theory and Practice, 36(2), 237-265.

Haynie, J. M., Shepherd, D., Mosakowski, E., \& Earley, P. C. (2010). A situated metacognitive model of the entrepreneurial mindset. Journal of Business Venturing, 25(2), 217-229. 
Hayward, M. L., Shepherd, D. A., \& Griffin, D. (2006). A hubris theory of entrepreneurship. Management Science, 52(2), 160-172.

Helweg-Larsen, M., \& Shepperd, J. (2001). Do moderators of the optimistic bias affect personal or target risk estimates? Personality and Social Psychology Review 5, 74-95.

Hmieleski, K. M., \& Baron, R. A. (2009). Entrepreneurs' optimism and new venture performance: A social cognitive perspective. Academy of Management Journal, 52(3), 473488.

Huber, L., Sloof, R. \& Van Praag M. (2014). The effect of early entrepreneurship education: Evidence from a field experiment. European Economic Review 72, 76-97.

Jovanovic, B. (1982). Selection and the evolution of industry. Econometrica 50, 649-670

Keh, H., Foo, M., \& Lim, B. (2002). Opportunity evaluation under risky conditions: The cognitive processes of entrepreneurs. Entrepreneurship Theory and Practice, 27(2), 125148.

Kirzner, I. M. (1979). Perception, opportunity, and profit: Studies in the theory of entrepreneurship. University of Chicago press.

Koellinger, P. (2008). Why are some entrepreneurs more innovative than others? Small Business Economics, 31(1), 21-37.

Koellinger, P., Minniti, M., \& Schade, C. (2007). “I think I can, I think I can”: Overconfidence and entrepreneurial behavior. Journal of Economic Psychology, 28(4), 502-527.

Kor, Y. Y., Mahoney, J. T., \& Michael, S. C. (2007). Resources, capabilities and entrepreneurial perceptions. Journal of Management Studies, 44(7), 1187-1212.

Krueger, N. F. (1993). The impact of prior entrepreneurial exposure on perceptions of new venture feasibility and desirability. Entrepreneurship Theory and Practice, 18(1), 5-21.

Krueger, N. F. (2003). The cognitive psychology of entrepreneurship. In Handbook of entrepreneurship research (pp. 105-140). Springer US.

Krueger, N. F. (2007). What lies beneath? The experiential essence of entrepreneurial thinking. Entrepreneurship Theory and Practice, 31(1), 123-138.

Krueger, N., \& Dickson, P. (1994). How believing in ourselves increases risk taking: perceived self-efficacy and opportunity recognition. Decision Sciences, 25, 385-400.

Kwong, C., Jones-Evans, D., \& Thompson, P. (2012). Differences in perceptions of access to finance between potential male and female entrepreneurs: Evidence from the UK. International Journal of Entrepreneurial Behavior \& Research, 18(1), 75-97.

Landier, A., \& Thesmar, D. (2009). Financial contracting with optimistic entrepreneurs. Review of Financial Studies, 22(1), 117-150. 
Laussel, D., \& Le Bron, M. (1995). A general equilibrium theory of firm formation based on individual unobservable skills. European Economic Review, 39, 1303-1319.

Lazear, E. (2004). Balanced Skills and Entrepreneurship. American Economic Review, 94, 208211.

Lazear, E. (2005). Entrepreneurship. Journal of Labor Economics, 23, 649-680.

Lee, B., O'Brien, J. and Sivaramakrishnan, K. (2008). An analysis of financial analysts' optimism in long-term growth forecasts. Journal of Behavioral Finance, 9(3), 171-184.

Levesque, M., \& Minniti, M. (2006). The effect of aging on entrepreneurial behavior. Journal of Business Venturing, 21, 177-194.

Levinthal, D., \& March, J. (1993). The myopia of learning. Strategic Management Journal, 14(S2), 95-112.

Markman, G. D., Balkin, D. B., \& Baron, R. A. (2002). Inventors and new venture formation: the effects of general self-efficacy and regretful thinking. Entrepreneurship Theory and Practice, 27(2), 149-165.

McCann, B. T., \& Vroom, G. (2015). Opportunity evaluation and changing beliefs during the nascent entrepreneurial process. International Small Business Journal, 33(6), 612-637.

McMullen, J. S., \& Shepherd, D. A. (2006). Entrepreneurial action and the role of uncertainty in the theory of the entrepreneur. Academy of Management Review, 31(1), 132-152.

Miller, D., 1986. Configurations of strategy and structure: towards a synthesis. Strategic Management Journal 7, 233-249.

Miller, D., 1996. Configurations revisited. Strategic Management Journal 17,505-512.

Mitchell, J. R., \& Shepherd, D. A. (2010). To thine own self be true: Images of self, images of opportunity, and entrepreneurial action. Journal of Business Venturing, 25(1), 138-154.

Mitchell, R. K., Busenitz, L. W., Bird, B., Gaglio, C. M., McMullen, J. S., Morse, E. A., \& Smith, J. B. (2007). The central question in entrepreneurial cognition research 2007. Entrepreneurship Theory and Practice, 31(1), 1-27.

Mitchell, R. K., Busenitz, L. W., Lant, T., McDougall, P. P., Morse, E. A., \& Smith, J. B. (2004). The distinctive and inclusive domain of entrepreneurial cognition research. Entrepreneurship Theory and Practice, 28(6), 505-518.

Mitchell, R. K., Busenitz, L., Lant, T., McDougall, P. P., Morse, E. A., \& Smith, J. B. (2002). Toward a theory of entrepreneurial cognition: Rethinking the people side of entrepreneurship research. Entrepreneurship Theory and Practice, 27(2), 93-104.

Mitchell, R. K., Smith, B., Seawright, K. W., \& Morse, E. A. (2000a). Cross-cultural cognitions and the venture creation decision. Academy of Management Journal, 43(5), 974-993. 
Neck, H., \& Greene, P., (2011). Entrepreneurship Education: Known Worlds and New Frontiers. Journal of Small Business Management, 49, 55-70.

Nguyen, H., Johnson, A., Collins, C. and Parker, S. K. (2017). Confidence Matters: Selfefficacy Moderates the Credit that Supervisors Give to Adaptive and Proactive Role Behaviours. British Journal of Management, 28, 315-330.

Oosterbeek, H., van Praag, M. \& Ijsselstein, A. (2010). The impact of entrepreneurship education on entrepreneurship skills and motivation. European Economic Review 54, $442-$ 454.

Ozgen, E., \& Baron, R. (2007). Social sources of information in opportunity recognition: Effects of mentors, industry networks, and professional forums. Journal of Business Venturing, 22(2), 174-192.

Peterson, C. (2000). The future of optimism. American Psychologist, 55, 44-55.

Pillai, K. G. (2010). Managers' Perceptual Errors Revisited: the Role of Knowledge Calibration. British Journal of Management, 21, 299-312.

Rabin, M. (1998). Psychology and economics. Journal of Economic Literature, 36(1), 11-46.

Rego, A., Sousa, F., Marques, C., \& Cunha, M. P. E. (2012). Optimism predicting employees' creativity: The mediating role of positive affect and the positivity ratio. European Journal of Work and Organizational Psychology, 21(2), 244-270.

Reynolds, P., Bosma, N., Autio, E., Hunt, S., De Bono, N., Servais, I., Lopez-Garcia, P. \& Chin, N. (2005). Global entrepreneurship monitor: Data collection design and implementation 1998-2003. Small Business Economics, 24(3), 205-231.

Riketta, M. and Nienaber, S. (2007). Multiple Identities and Work Motivation: The Role of Perceived Compatibility between Nested Organizational Units. British Journal of Management, 18, S61-S77.

Robertson, I. T. and Sadri, G. (1993). Managerial Self-efficacy and Managerial Performance. British Journal of Management, 4, 37-45.

Ryan, R., \& Deci, E. (2000). Self-determination theory and the facilitation of intrinsic motivation, social development, and well-being. American Psychologist, 55(1), 68-78.

Scherer, R., Adams, J., Carley, S., \& Wiebe, F. (1989). Role model performance effects on development of entrepreneurial career preference. Entrepreneurship, Theory and Practice, 13(3), 53-71.

Shane, S. (2009). Why encouraging more people to become entrepreneurs is bad public policy. Small Business Economics, 33(2), 141-149. 
Shook, C. L., Priem, R. L., \& McGee, J. E. (2003). Venture creation and the enterprising individual: A review and synthesis. Journal of Management, 29(3), 379-399.

Simon, M., Houghton, S. M., \& Aquino, K. (2000). Cognitive biases, risk perception, and venture formation: How individuals decide to start companies. Journal of Business Venturing, 15(2), 113-134.

Schmitt, A., Gielnik, M. M., Zacher, H., \& Klemann, D. K. (2013). The motivational benefits of specific versus general optimism. The Journal of Positive Psychology, 8(5), 425-434.

Smith, J. B., Mitchell, J. R., \& Mitchell, R. K. (2009). Entrepreneurial scripts and the new transaction commitment mindset: Extending the expert information processing theory approach to entrepreneurial cognition research. Entrepreneurship Theory and Practice, $33(4), 815-844$.

Starr, J. A., \& Bygrave, W. D. (1991). The assets and liabilities of prior start-up experience: An exploratory study of multiple venture entrepreneurs. In N.C. Churchill et al. (Eds.), Frontiers of Entrepreneurship Research, 213-227. Babson Park, MA: Babson College

Storey, D. J. (2011). Optimism and chance: The elephants in the entrepreneurship room. International Small Business Journal, 29(4), 303-321.

Tichy, G. (2004). The over-optimism among experts in assessment and foresight. Technological Forecasting and Social Change, 71(4), 341-363.

Trevelyan, R. (2008). Optimism, overconfidence and entrepreneurial activity. Management Decision, 46(7), 986-1001

Ucbasaran, D., Westhead, P., Wright, M., \& Flores, M. (2010). The nature of entrepreneurial experience, business failure and comparative optimism. Journal of Business Venturing, 25(6), 541-555.

Walker, E., \& Brown, A. (2004). What success factors are important to small business owners? International Small Business Journal, 22(6), 577-594.

Westhead, P., \& Wright, M. (2011). David Storey's optimism and chance perspective: A case of the Emperor's new clothes?. International Small Business Journal, 29(6), 714-729.

Wood, R., \& Bandura, A. (1989). Social cognitive theory of organizational management. Academy of Management Review, 14, 361-384.

Wood, M. S., Bradley, S. W., \& Artz, K. (2015). Roots, reasons, and resources: Situated optimism and firm growth in subsistence economies. Journal of Business Research, 68(1), 127-136.

Wright, M., Robbie, K. \& Ennew, C. (1997). Venture capitalists and serial entrepreneurs. Journal of Business Venturing 12, 227-249. 
Wright, M., Robbie, K. and Ennew, C. (1997). Serial Entrepreneurs. British Journal of Management, 8, 251-268.

Zacher, H., \& Frese, M. (2011). Maintaining a focus on opportunities at work: The interplay between age, job complexity, and the use of selection, optimization, and compensation strategies. Journal of Organizational Behavior, 32(2), 291-318.

Zahra, S., Korri, J., \& Yu, J. (2005). Cognition and international entrepreneurship: implications for research on international opportunity recognition and exploitation. International Business Review, 14, 129-146. 


\begin{tabular}{|c|c|c|c|c|c|}
\hline Variable Name & Variable Description & Mean & $\begin{array}{l}\text { Std. } \\
\text { Dev. }\end{array}$ & Min & Max \\
\hline Age & Age ( years) & 42.54 & 14.948 & 18 & 99 \\
\hline Gender & Gender Male $=1$ and female $=0$ & 0.48 & 0.5 & 0 & 1 \\
\hline Optimism & $\begin{array}{l}\text { Composite index computed by using } \\
\text { replies to } 3 \text { questions on startup skills, the } \\
\text { perception of future business opportunities } \\
\text { and fear to fail. }\end{array}$ & 1.51 & 0.963 & 0 & 3 \\
\hline Social capital & $\begin{array}{l}\text { You know someone personally who started } \\
\text { a business in the past two years. Dummy } \\
\text { variable with agree }=1 \text { and disagree }=0\end{array}$ & 0.36 & 0.481 & 0 & 1 \\
\hline Societal acceptance & $\begin{array}{l}\text { Societal acceptance of entrepreneurship as } \\
\text { a career option. }\end{array}$ & 1.94 & 0.965 & 0 & 3 \\
\hline Non-entrepreneurs & $\begin{array}{l}\text { Non-entrepreneurs (with no previous } \\
\text { entrepreneurial experience) }\end{array}$ & 0.841 & 0.365 & 0 & 1 \\
\hline $\begin{array}{l}\text { Potential } \\
\text { entrepreneurs }\end{array}$ & $\begin{array}{l}\text { You are, alone or with others, expecting to } \\
\text { start a new business, including any type of } \\
\text { self-employment, within the next three } \\
\text { years. Dummy variable with agree }=1 \text { and } \\
\text { disagree }=0\end{array}$ & 0.18 & 0.38 & 0 & 1 \\
\hline $\begin{array}{l}\text { Nascent } \\
\text { entrepreneurs }\end{array}$ & $\begin{array}{l}\text { Actively involved in start-up effort, owner, } \\
\text { and no wages yet. Dummy variable with } \\
\text { yes }=1 \text { and no }=0\end{array}$ & 0.05 & 0.215 & 0 & 1 \\
\hline Baby business & $\begin{array}{l}\text { Manages and owns a business that is up to } \\
42 \text { months old. Dummy variable with yes } \\
=1 \text { and no }=0\end{array}$ & 0.04 & 0.198 & 0 & 1 \\
\hline $\begin{array}{l}\text { Established } \\
\text { business }\end{array}$ & $\begin{array}{l}\text { Manages and owns a business that is older } \\
\text { than } 42 \text { months. Dummy variable with yes } \\
=1 \text { and no }=0\end{array}$ & 0.07 & 0.262 & 0 & 1 \\
\hline
\end{tabular}


Table 2: Correlations among Independent Variables

\begin{tabular}{|c|c|c|c|c|c|c|c|c|c|c|}
\hline & Variables & 1 & 2 & 3 & 4 & 5 & 6 & 7 & 8 & 9 \\
\hline 1 & Gender & 1 & & & & & & & & \\
\hline 2 & Age (log) & $0.033 * *$ & 1 & & & & & & & \\
\hline 3 & Non-entrepreneurs & $0.113 * *$ & $-0.011 * *$ & 1 & & & & & & \\
\hline 4 & Potential entrepreneurs & $-0.070 * *$ & $-0.208 * *$ & $-0.214 * *$ & 1 & & & & & \\
\hline 5 & Nascent entrepreneurs & $-0.049 * *$ & $-0.068 * *$ & $-0.511 * *$ & $0.255^{* *}$ & 1 & & & & \\
\hline 6 & Baby business & $-0.041 * *$ & $-0.060 * *$ & $-0.473 * *$ & $0.112 * *$ & $-0.004 * *$ & 1 & & & \\
\hline 7 & Established business & $-0.093 * *$ & $0.080 * *$ & $-0.659 * *$ & $-0.030 * *$ & $-0.020 * *$ & $-0.049 * *$ & 1 & & \\
\hline 8 & Societal acceptance & -0.001 & $-0.048 * *$ & $-0.053 * *$ & $0.132 * *$ & $0.047 * *$ & $0.041 * *$ & $0.006 * *$ & 1 & \\
\hline 9 & Social capital & $-0.097 * *$ & $-0.158 * *$ & $-0.193 * *$ & $0.201 * *$ & $0.129 * *$ & $0.121 * *$ & $0.085 * *$ & $0.044 * *$ & 1 \\
\hline
\end{tabular}

$* \mathrm{p}<0.010 ; * * \mathrm{p}<0.005 ; * * * \mathrm{p}<0.001$ 
Table 3: Length of Entrepreneurial Experience and Optimism

\begin{tabular}{|c|c|c|c|c|c|c|c|}
\hline \multicolumn{8}{|c|}{ Dependent Variable (Optimism about Future Business Opportunities) } \\
\hline Control Variables & Model 1 & Model 2 & Model 3 & Model 4 & Model 5 & Model 6 & Model 7 \\
\hline Gender & $-0.272 * * *$ & $-0.219 * * *$ & $-0.244 * * *$ & $-0.259 * * *$ & $-0.263 * * *$ & $-0.248 * * *$ & $-0.201 * * *$ \\
\hline$(\log )$ Age & $-0.045 * * *$ & $-0.074 * * *$ & $-0.030 * * *$ & $-0.032 * * *$ & $-0.038 * * *$ & $-0.083 * * *$ & -0.004 \\
\hline Year dummies & Yes & Yes & Yes & Yes & Yes & Yes & Yes \\
\hline Country dummies & Yes & Yes & Yes & Yes & Yes & Yes & Yes \\
\hline \multicolumn{8}{|l|}{ Independent Variables } \\
\hline Non-entrepreneurs & & $-0.558 * * *$ & & & & & \\
\hline Potential entrepreneurs & & & $0.502 * * *$ & & & & $0.431 * * *$ \\
\hline Nascent entrepreneurs & & & & $0.558 * * *$ & & & $0.466 * * *$ \\
\hline Baby business & & & & & $0.490 * * *$ & & $0.527 * * *$ \\
\hline Established business & & & & & & $0.417 * * *$ & $0.461 * * *$ \\
\hline Adjusted R2 & 0.144 & 0.191 & 0.182 & 0.161 & 0.155 & 0.158 & 0.220 \\
\hline Number of observations & 459581 & 459581 & 459581 & 459581 & 459581 & 459581 & 459581 \\
\hline
\end{tabular}

$* \mathrm{p}<0.010 ; * * \mathrm{p}<0.005 ; * * * \mathrm{p}<0.001$

Note: OLS coefficients are reported in the table.

Figure 1: Length of Entrepreneurial Experience and Optimism about Future Entrepreneurial Opportunities.

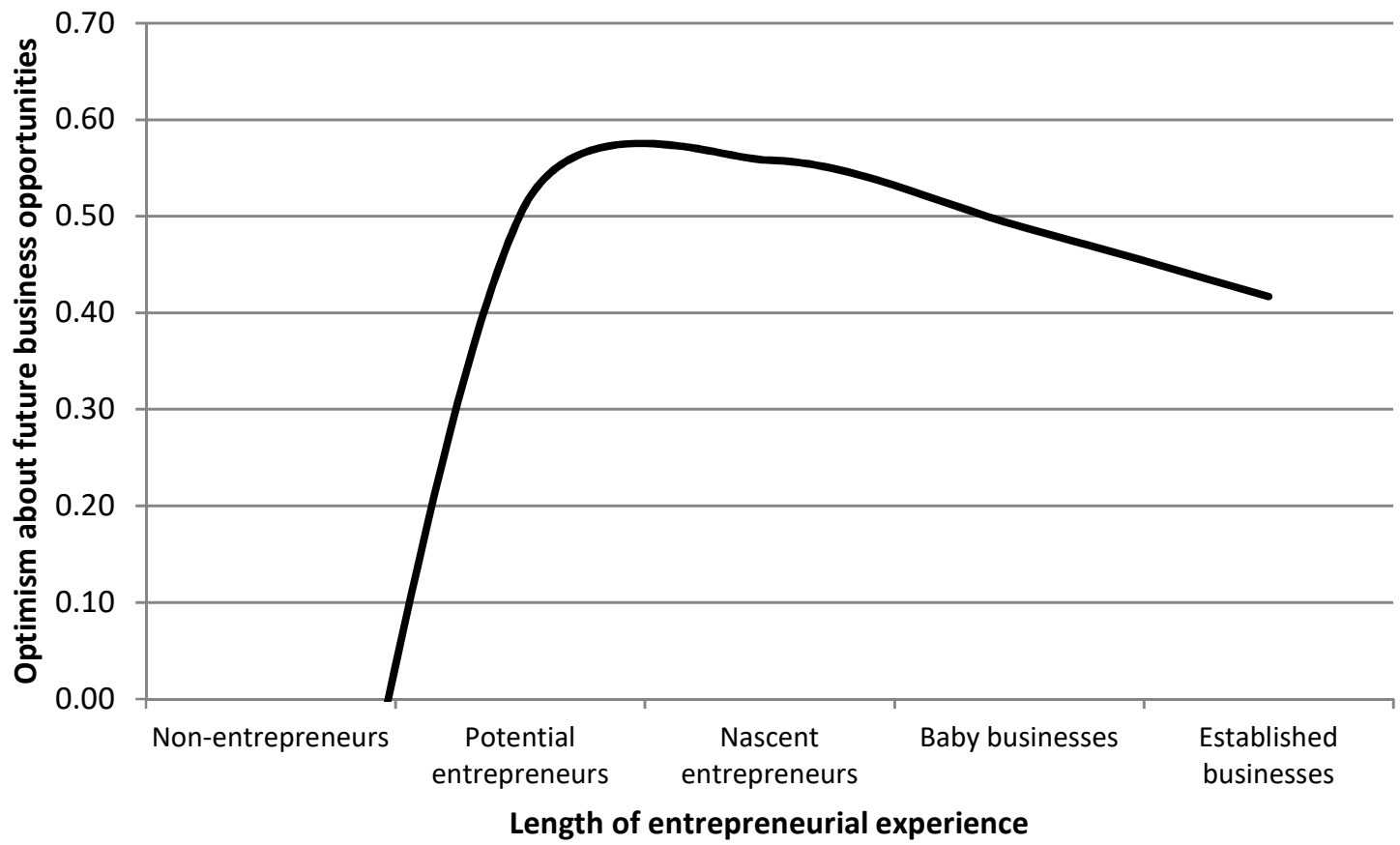

Table 4: Length of Entrepreneurial Experience, Optimism about Future Entrepreneurial Opportunities, and Moderators, OLS Estimates 


\begin{tabular}{|c|c|c|c|c|c|c|c|}
\hline \multicolumn{8}{|c|}{ Dependent Variable (Optimism about Future Business Opportunities) } \\
\hline Control Variables & Model 1 & Model 2 & Model 3 & Model 4 & Model 5 & Model 6 & Model 7 \\
\hline Gender & $-0.219 * * *$ & $-0.183 * * *$ & $-0.204 * * *$ & $-0.212 * * *$ & $-0.214 * * *$ & $-0.203 * * *$ & $-0.171 * * *$ \\
\hline$(\log )$ Age & $0.021 * * *$ & $-0.023 * * *$ & $0.077 * * *$ & $0.027 * * *$ & $0.023 * * *$ & $-0.017 * * *$ & $0.034 * * *$ \\
\hline Year dummies & Yes & Yes & Yes & Yes & Yes & Yes & Yes \\
\hline Country dummies & Yes & Yes & Yes & Yes & Yes & Yes & Yes \\
\hline \multicolumn{8}{|l|}{ Independent Variables } \\
\hline Non-entrepreneurs & & $-0.448 * * *$ & & & & & \\
\hline Potential entrepreneurs & & & $0.388 * * *$ & & & & $0.361 * * *$ \\
\hline Nascent entrepreneurs & & & & $0.426 * * *$ & & & $0.397 * * *$ \\
\hline Baby business & & & & & $0.361 * * *$ & & $0.441 * * *$ \\
\hline Established business & & & & & & $0.313 * * *$ & $0.391 * * *$ \\
\hline Societal acceptance & $0.056 * * *$ & $0.056 * * *$ & $0.048 * * *$ & $0.055 * * *$ & $0.056 * * *$ & $0.057 * * *$ & $0049 * * *$ \\
\hline Social capital & $0.371 * * *$ & $0.314 * * *$ & $0.329 * * *$ & $0.348 * * *$ & $0.356 * * *$ & $0.358 * * *$ & $0.276^{* * *}$ \\
\hline Adjusted $\mathrm{R}^{2}$ & 0.194 & 0.226 & 0.220 & 0.206 & 0.201 & 0.203 & 0.249 \\
\hline Number of observations & 192399 & 192399 & 187632 & 192399 & 192399 & 192399 & 187632 \\
\hline
\end{tabular}

Note: OLS coefficients are reported in the table.

Figure 2: Length of Entrepreneurial Experience, Optimism about Future Entrepreneurial Opportunities, and Moderators.

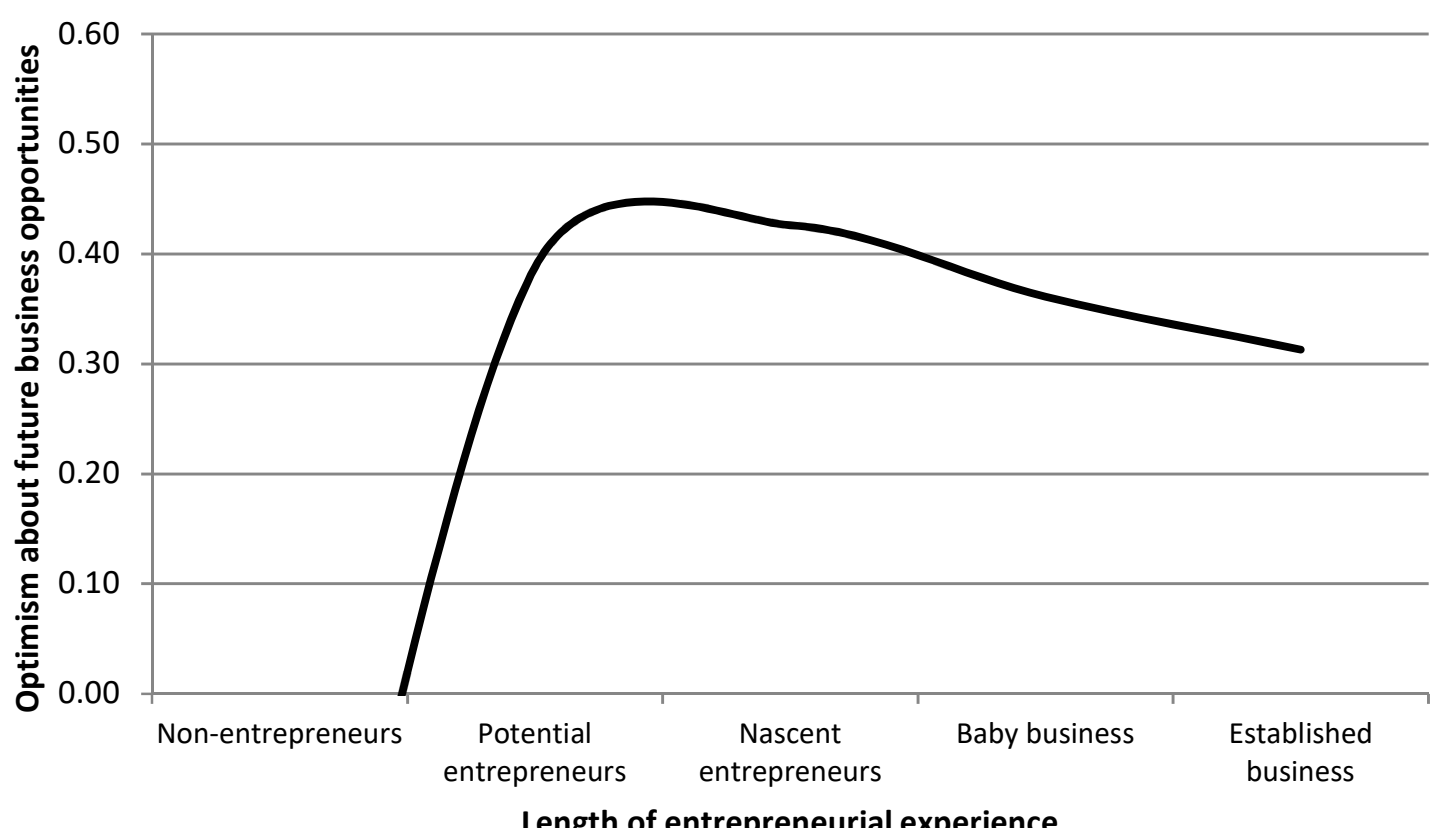

Table 5: Length of Entrepreneurial Experience, Optimism about Future Entrepreneurial Opportunities, Moderators and Interactions, OLS Estimates

Dependent Variable (Optimism about Future Business Opportunities) 


\begin{tabular}{|c|c|c|c|c|c|c|c|}
\hline Control Variables & Model 1 & Model 2 & Model 3 & Model 4 & Model 5 & Model 6 & Model 7 \\
\hline Gender & $-0.219 * * *$ & $-0.183 * * *$ & $-0.204 * * *$ & $-0.212 * * *$ & $-0.214 * * *$ & $-0.203 * * *$ & $-0.171 * * *$ \\
\hline (log) Age & $0.021 * * *$ & $-0.023 * * *$ & $0.079 * * *$ & $0.028 * * *$ & $0.024 * * *$ & $-0.016 * * *$ & $0.034 * * *$ \\
\hline Year dummies & Yes & Yes & Yes & Yes & Yes & Yes & Yes \\
\hline Country dummies & Yes & Yes & Yes & Yes & Yes & Yes & Yes \\
\hline \multicolumn{8}{|l|}{ Independent Variables } \\
\hline Non-entrepreneurs & & $-0.448 * * *$ & & & & & \\
\hline Potential entrepreneurs (P.E.) & & & $0.457 * * *$ & & & & $0.406^{* * *}$ \\
\hline Nascent entrepreneurs (N.E.) & & & & $0.606 * * *$ & & & $0.511 * * *$ \\
\hline Baby business (B.B.) & & & & & $0.414 * * *$ & & $0.467 * * *$ \\
\hline Established business (E.B.) & & & & & & $0.390 * * *$ & $0.511 * * *$ \\
\hline Societal acceptance (S.A.) & $0.056 * * *$ & $0.056 * * *$ & $0.048 * * *$ & $0.057 * * *$ & $0.056 * * *$ & $0.059 * * *$ & $0.047 * * *$ \\
\hline Social capital (S.C.) & $0.371 * * *$ & $0.314 * * *$ & $0.368 * * *$ & $0.361 * * *$ & $0.361 * * *$ & $0.367 * * *$ & $0.328 * * *$ \\
\hline P.E. * S.A. & & & 0.005 & & & & $0.013 * *$ \\
\hline P.E. * S.C. & & & $-0.150 * * *$ & & & & $-0.138 * * *$ \\
\hline N.E. * S.A. & & & & $-0.028 * * *$ & & & $-0.024 * * *$ \\
\hline N.E. * S.C. & & & & $-0.197 * * *$ & & & $-0.102 * * *$ \\
\hline B.B. * S.A. & & & & & 0.003 & & 0.004 \\
\hline B.B. * S.C. & & & & & $-0.095^{* * *}$ & & $-0.057 * * *$ \\
\hline E.B. * S.A. & & & & & & $-0.017 * * *$ & -0.002 \\
\hline E.B. * S.C. & & & & & & $-0.088 * * *$ & $-0.050 * * *$ \\
\hline Adjusted $\mathrm{R}^{2}$ & 0.194 & 0.226 & 0.221 & 0.206 & 0.202 & 0.203 & 0.249 \\
\hline Number of observations & 192399 & 192399 & 187632 & 192399 & 192399 & 192399 & 187632 \\
\hline
\end{tabular}

$* \mathrm{p}<0.010 ; * * \mathrm{p}<0.005 ; * * * \mathrm{p}<0.001$

Note: OLS coefficients are reported in the table. 
Figure 3: Relationship between Optimism and Length of Entrepreneurial Experience with Societal Acceptance (SA) as moderator

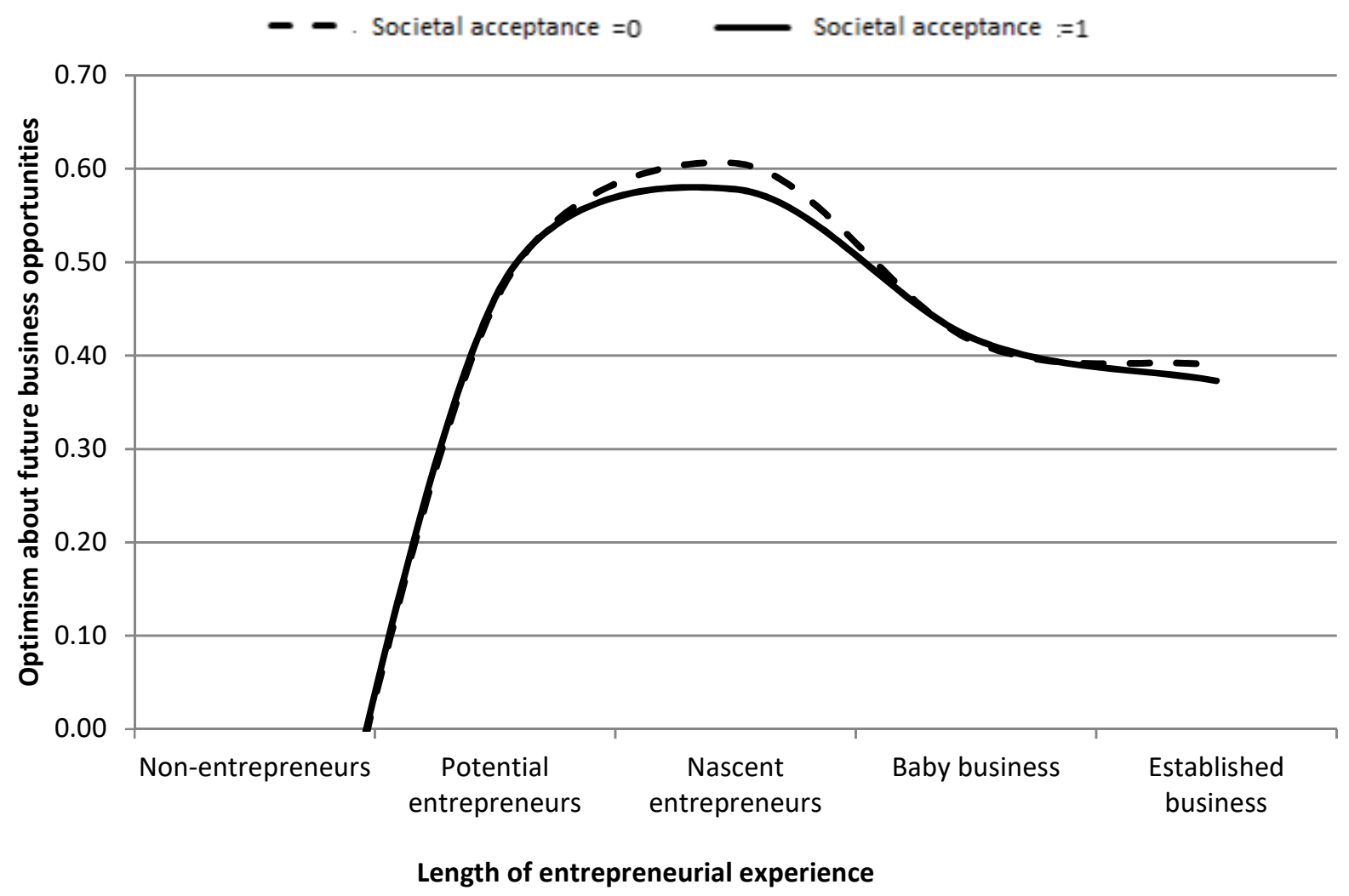


Figure 4: Relationship between Optimism and Length of Entrepreneurial Experience with Social Capital (SC) as moderator

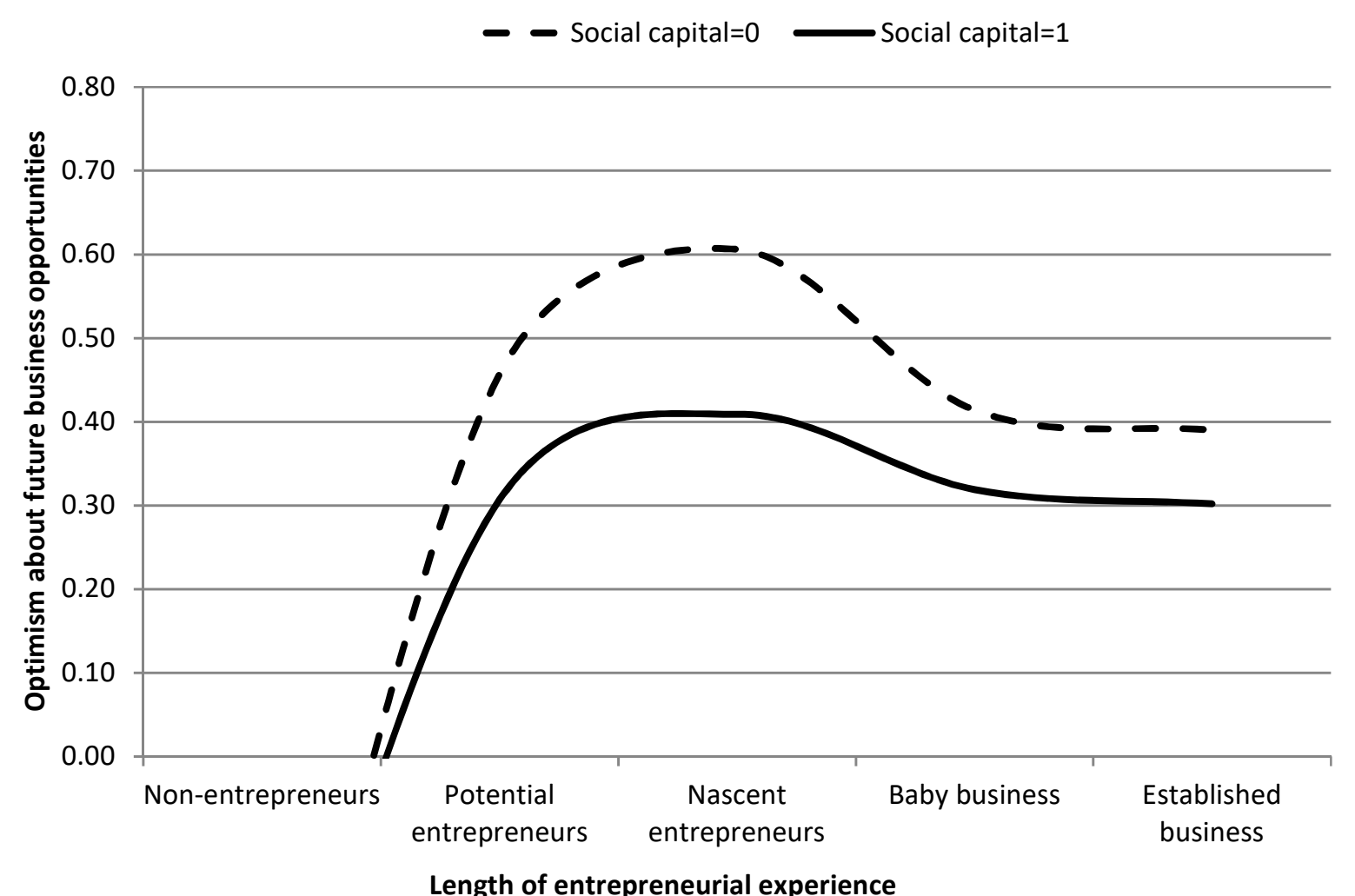

